\title{
PREPOSITIONAL PHRASES WITH VERBA DICENDI FROM DALMATIN'S TRANSLATION OF THE BIBLE (1584) IN RELATION TO FOREIGN LANGUAGE TRANSLATIONS
}

\section{INTRODUCTION}

In a diachronic perspective from the 16th century to the present, this article investigates translated interlinguistic agreement and difference in the use of the temporally marked Slovenian prepositional phrases that appeared in the semantic group of verba dicendi in the first two books of the Old Testament and the New Testament of the oldest Slovenian translation of the Bible, from 1584, and that were replaced in the modern literary language in the 19th century by the introduction of prepositionless or other prepositional patterns. A comparison is made on the basis of Internet publications of parallel sections of six foreign language translations (Latin, German, two English [17th century and modern], French and Russian), and the extent to which these prepositional phrases are covered by older or modern literary Slovenian syntactic patterns is determined.

\section{PREPOSITIONAL PHRASES WITH VERBA DICENDI IN A DIACHRONIC PERSPECTIVE}

1.0 For the older period of literary Slovenian, from the diachronic perspective the differential use of prepositional phrases is significant, especially in certain syntactic senses with verb phrases with free prepositional morphemes, known as prepositional verbs, in verb phrases and in certain figurative meanings that were adopted on the model of foreign language literary patterns (in this case, on the basis of Biblical pattern), and therefore a certain interlinguistic agreement, and even interlinguistic universality of equivalent prepositional phrases in the valency of obligatory and nonobligatory syntactic senses in a particular time are expected, and on the other hand deviation in the direction of differential linguistic specifics as well.

1.1.0 The sample group of prepositional phrases that was selected with regard to a developmentally disproportional distribution of use in Slovenian and great lexical frequency is limited to a comparison of right valence prepositional complements as part of the semantic field of structurally similar verba dicendi such as govoriti, odgovoriti, reči, praviti, dejati, povedati, klicati, vpiti, pridigati, etc. that from the 16 th century up to the 19th century partially corresponded to the model govoriti/reči ... h komu kaj od koga/česa (skozi koga/kaj), for which the omission of the use of prepositional free morphemes and especially the substitution of non-Slovenian calqued prepositional 
phrases with suitable native elements (e.g., govoriti, reči... komu kaj o kom/čem (po $\mathrm{kom} / \mathrm{v} \check{\mathrm{c} e m}, \mathrm{~s}$ čim) is typical in historical development. To show which prepositional structures agree with those in foreign languages, interlinguistic comparison will cover a number of such prepositional phrases from the first two books of the Old Testament and New Testament in six different languages and eight translations. These are: Dalmatin's Bible from 1584 (DAL), the Slovenian standard translation from 1996 (SSP), Luther's German Bible from 1545 (L45), the Latin Vulgate from the 4th to 5th century (VUL), the English King James translation from 1611 (KJV) and modern English (the Good News Bible, GNB), a French translation from 1910 (Louis Segond, SEG) and the Russian synodal translation from 1876 (RUS). The results were verified with the same Latin and German foreign language phrases in Hutter's six-language Biblia sacra (1599), which did not significantly differ from the samples in the two editions mentioned above.

1.1.1 All of the prepositional phrases mentioned above primarily express spatial relations. Their figurative use, which in Slovenian linguistics this is defined as calqued, semantically also derives from them and, with a link to the abstraction of the spatial component, expands its usage to verbs that express this semantic relationship at the figurative, metaphorical level, which would agree with the prototype theory of prepositional meaning and the radial interpretation of the cognitive linguistics approach (Sicherl 2000, 416-420). Prepositions - as polysemously complex relators or a subtype of junctors that prototypically connect a given base with a nominal or pronominal adjunct and distinguish three determining types or syntactic functions: attributive, predicative and applicative, in which the base is a noun, a subject and a copula as well as a verb (Weinrich 1993, 610) - show a varying degree of preservation of the original sense, which is partially lost (made meaningless), and take on the grammatical function of what are known as free morphemes, the semantic trace of which is nonetheless marked (with selected verbs, the orientation of the verbal action toward the participant in the communication as opposed to the goal with the free dative), while their exchangeability with non-prepositional verbs defines their non-obligatory nature or non-necessity in synthetic languages as opposed to analytical languages.

1.2 The sample studied is limited to the semantic group of verba dicendi, which František Daneš $(1999,105-106)$ defined as verbs of action whose agentive participant is the agent of an action based on the use of language in its spoken (auditory), graphic or figurative shape and express only a spoken activity or its content or thought (goal, function) and have the role of performatives (e.g., opravičiti se, ukazati, prisiliti, prosi$t i$, etc.) with a declarative function (termed illocutionary power by Austin) in which the use of language is only one of the possible means for attaining the same goal. A similar basic scheme of obligatory and non-obligatory participant complements is characteristic for all of them.

1.2.1 In Dalmatin the right argument role that names the person responded to with verba dicendi is the most numerous, for example: the most general unidirectional or bidirectional communicative verb govoriti, the typical unidirectional reči, less often 
porec $i$, the grammatically limited verb dejati, which, like today, appeared only with a temporal-functionally expressed limitation on the past (the type je djal 'said'), izgo voriti, exceptionally praviti, DAL: GOSPVD Bug je djal k'Sheni (Gen. 3.13), $k$ 'Sheni je on rekàl (Gen. 3.16); SSP: GOSPOD Bog je rekel ženi; ženi je rekel). In the four books of the Bible mentioned, in Dalmatin the verb dejati is most frequently used, with nearly one thousand attestations, with a formal-temporal limitation on the reporting of past verbal actions that primarily introduce a literal quotation or report it, and with it the free morpheme $k / h$ consistently appears. It follows the verb rec $i$ with nearly 450 attestations - which, however, in cases with a stated receiver of the message expressed with a dative participant does not always realize the morpheme $k$ with itself (14 times)), and a content complement does not appear with it. In third place is the verb govoriti (over 200), which appears in two distinct forms of the past participle, govoril and govuril, which surprisingly appear in a two-to-one relationship at the expense of the non-Lower Carniolan phonetic variant ( 86 to 46 ), whereas the entirety of examples from all available books exhibits a diametrically opposed picture (145 to 272). Next is povedati (approximately 180), which does not require a free morpheme, e.g. DAL: de fte timu Moshu povedali (Gen. 46.31). The verb praviti is more rarely represented (approximately 70 examples), and is usually followed by a literal quotation, and otherwise the morpheme may be given or not: DAL: od kateriga je Bug njemu pravil (Gen. 22.3). Usage without the prepositional morpheme sporadically appears (e.g., Gen. 19.12, 34.11, 41.55, Mt 22.13, Mk 3. 9, etc.). In analytical languages it is expressed with a complement for the indirect participant in the action, which also implies the orientation of the verbal action (KJV: the LORD God said unto the woman; GNB: and he said to the woman; KJV: Unto the woman he said; SEG: l'Eternel Dieux dit à sa femme; L45: da sprach GOtt der HErr zum Weibe, whereas in Russian a bare dative is used (I skazal Gospodb Bog žene; žene skazal), and in Latin both usages are attested (et dixit Dominus Deus ad mulierem, mulieri quoque dixit ei - dixit ad eum, dixit mihi, dixit Sarai uxori suae,etc.), which also occurs in French with a personal pronoun complement (Ils lui dirent), and in German only with the verb sagen, and not sprechen (Und sie sagten ihm versus und sprach zu ihm).

1.2.2.1 The basic bivalent grammatical pattern of the verb govoriti, which alone anticipates bidirectional communication $\left(\mathrm{S}_{\mathrm{N}}\right.$ (+hum.) V (govoriti) $\mathrm{S}_{\mathrm{I}}$ (+hum.) 'govoriti s kom' 'to speak with someone'), was also dominant in the 16th century, and in the modern translation is substituted for with unidirectional verbal action ( $s^{\prime}$ /vojim fynom Esavom govoril; SSP: govoril sinu Ezavu (Gen. 27.5)), whereas unidirectional verbal action of the subject is designated (directed) toward the listener or inter-

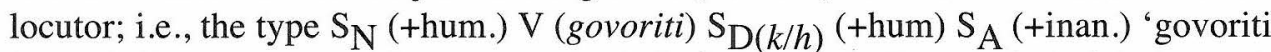
komu kaj' 'to say something to someone': (od)govoriti, reči, povedati, dejati, pravi$t i$, poročati, komu kaj in the 16th century was very often expressed by a prepositional dative with the free morpheme $k$ (e.g., govoriti $h$ komu kaj), and one also finds complements without it, always with the verb povedati. The unidirectional verb, the perfective pair of the upper (odgovoriti), which appears rarely (16) and generally has 
no complement (e.g., Moses je pak timu Folku odgovoril (Ex. 20.20)), which also agrees with the government of the German verb (e.g., Mose antwortete ihm), also does not appear with a prepositional morpheme in the 16th century (the type (odgovoriti komu kaj), which corresponds to the German translation, in which the verb odgovoriti (antworten) does not have the free morpheme $z u$, and therefore it also does not exist in Slovenian. Russian is similar, where the response to the participant in the message is rarely stated, whereas in French and Latin the free morpheme for the indirect object is also found with this verb (e.g., et répondit à Abraham). A prepositional morpheme is not always found with the verb reči (reči komu kaj), e.g. DAL: Jeft hozhem gori pojti inu Pharaonu povédati, inu hozhem k'njemu rezhi; SSP: Pojdem poročat faraonu in mu rečem (Gen. 46.31), where it corresponds with the German text: und Pharao ansagen und zu ihm sprechen; GNB: said to him, tell so.; KJV: say unto so., the Russian and Latin translation also have a bare dative (nunciabo Pharaoni dicamque ei). The verbs zapovedati and poročiti have only a bare dative (poročiti komu kaj 'to announce'), which agrees with German.

1.2.2.2 According to the theory of strong and weak syntactic variants, the use of a prepositional verb as opposed to a prepositionless verb could be defined with regard to the complexity of syntactic structures as more or less complex, which may be diachronically interpreted as a change from more complex structures to simpler structures.

1.2.3 With verbs that include semantic content of the manner (strength, intensity) of expression, such as vpiti, klicati h komu 'to cry, to call' the prepositional morpheme of directionality in Biblical texts is also preserved in all newer translations up to the most recent, and is also known in foreign language translations; e.g., DAL: vpili h'GOSPVDV (Ex. 17.4); SSP: je vpil h GOSPODU, although today's normative rules do not allow this valency possibility (only vpiti na koga/kaj, emphatic vpiti po kom/čem and prepositionless vpiti komu/kaj (e.g., orders to workers)).

1.2.4 With govoriti the prepositions proti and pred also sporadically appear in the role of orientation toward the interlocutor or location (DAL: Moses je pak pred GOSPVDOM govoril (Ex. 7.2), whereas the semantic opposition is expressed by zoper, which takes the accusative (supèr: DAL: govory supèr Synu (Mt 12.32)), which can also be preserved today (SSP: če kdo reče besedo zoper sina), pruti: DAL: je Jesus sazhel pruti folku govoriti ad Joannefa; SSP: je Jezus začel množicam govoriti o Janezu (Mt 11.7). In foreign translations there is no change in the prepositional morpheme $-k$ remains, whereas the phrase with od for the most part corresponds with an older translation (German von, Latin de, except English about in newer (in older concerning (KJV)) and Russian $(o, o b)$.

1.2.5.0 The object complement of content, substituted for by the preposition $o$ ( $\mathrm{S}_{\mathrm{Lo}^{+}}{ }^{\text {-hum. }}$ ) ('about someone/something'), the type govoriti, reči o kom/čem was expressed in the 16th century with the preposition od (govoriti od koga/česa), a free valency phrase of circumstance (a circumstant) that defines the verbal action with regard to the manner in which it is carried out or the mediator of the verbal action that is not also the agent of the action in the role of the subject was introduced in the 16th 
century with the preposition skozi, but in the standard Slovenian translation has been replaced by po for human mediators and by the prepositions $v$ and $z / s$ with nouns lexically and verbally defined for manner or communication.

1.2.5.1.1 With verbs of reporting, speaking, knowing and feeling, the typical prepositional phrase for a content object complement in the 16th century was expressed with the free morpheme od (the type govoriti od česa), which appears with the verbs brati, disputirati, govoriti, misliti, pisati, povedati, praviti, prerokovati, pridigovati, (za)slišati, (z)vedeti, vprašati, zamerkati, and zdeti ...od and with an appropriate noun that implies the meaning of the verbal communication (e.g., DAL: befsedo od krajleft$v a$ (Mt 13.19); SSP: besedo kraljestva), which was used in the literary language until the middle of the 19th century and is still found in Wolf's edition of the Bible of 1856 (except for vprašati od, where it is replaced by vprašati za), and is still alive in the spoken language today, where the meaning of the spatial starting point or separation, or in a metaphorical sense the origin of the verbal action or deduction, has already lost the sense of a semantic connection to spatial separation. Since the end of the 19th century it has been replaced by the morpheme $o(\check{c} e m)$, because there was a desire to root out the same surface structure as there was in German, upon which the Slovenian use is apparently based. A similar change is shown in English translations from various times expressing of - about (e.g., DAL: je on od nyh govuril; SSP: da govori o njih; KJV: that he spake of them; GNB: that he was talking about them (Mt 21.45). The Russian translation always contains the morpheme $o$, and the others are the equivalent of Slovenian od: German von, Latin and French de, except in the noun phrase, where the right non-agreeing attribute in the modern translation is a bare genitive, as in Latin (SSP: besedo kraljestva poslušati, VUL: verbum regni).

1.2.5.1.2 With the performative verb prositi the right human participant is expressed in the 16th century with an original od (e.g., prositi kaj od koga), while today this is a grammatically accusative object complement (prositi koga kaj): DAL: je eno rezh od njega prosila; SSP: da bi ga nekaj prosila; KJV: to want something from someone: desiring a certain thing of him; GNB: to ask for a favour: asked him for a favor, French differently, VUL: petens aliquid ab eo (Mt 20.20).

1.2.5.2 Non-obligatory prepositional phrases define the mediator of the verbal action (the type govoriti skozi koga) or define the manner of the utterance (e.g., go voriti skozi kaj), which proceeds from the meaning of transition within something from one end to the other, and according to the semantic shift expresses mediation (today more suitably with $p o$ ), spoken medium or means (the preposition $z / s$ čim), manner (the preposition $v$ čem, $s$ čim), purpose (to speak in memory [of]): govoriti v podobah, $z$ besedami, etc.; e.g., DAL: Satu jeft k'nym govorim Jkusi priglihe (Mt 13,13), SSP: Zato jim govorim $v$ prilikah, which is expressed with the preposition $v$ [in] all languages except in German, which has durch, corresponding to the Slovenian preposition. Passive structures also occur with verba dicendi when the agent (left participant) is unexpressed and, along with the active, it is often replaced in translations with Latin per, German durch: DAL: kar je govorjenu Jkusi Preroke (Mt 2.23); SSP: kar je bilo rečeno po prerokih). 


\section{CONCLUSION}

From an interlinguistic comparison of Biblical translations in the expression of the participant role with verba dicendi with regard to the use of bound and free (with regard to valency) prepositional verb phrases that do not express continuity in Slovenian, but were substituted for by a bare complement (the type govoriti, reči, etc. $h$ komu, prositi od koga), a semantically similar metaphorically used preposition (skozi - po) or an apparently semantically different prepositional morpheme $(o d-o)$, it is possible determine connections to or dependencies on foreign language translations that were often limited only to a German (or broader Germanic) grammatical linguistic example as an imitation of this, or to infer a mutual linguistic type or agreement at the level of prepositional phrase use in general, which probably derives from deep-structure semantic argumentation, as, for example, in the type govoriti od koga/česa the diachronic tendency is apparent to omit semantically undetermined prepositional use with verbs that express direct speech toward an interlocutor in the speech interaction as well as certain other verbal senses (with the sememe of association, approaching), as well as a tendency for semantic simplification or other semantic motivation of certain prepositions $(o d-o)$ in certain languages (Slovenian, English of - about) and with continuity in spoken linguistic practice. The tendency toward prepositional verbal forms in the older periods was, like other syntactic parallels, part of the heritage of Western European civilization and culture and was fostered by formal linguistic variation and similar semantic motivation. 


\section{BIBLIOGRAPHY}

HUTTER, Elias. 1599. Biblia sacra. Nuremberg.

: The Bible on the Internet:

- Dalmatin, Jurij. 1584 (2004). Biblia. Društvo svetopisemska družba Slovenije. (DAL)

- Slovenski standardni prevod (Slovenian standard translation). Second, revised edition, 1997. Copyright 1996, 2000. Društvo Svetopisemska družba Slovenije. (SSP)

- Good News Bible (Today's English Version). 1992. American Bible Society. (GNB)

- The Holy Bible (King James Version). 1611. Crown copyright, UK. (KJV)

- SEGOND, Louis. 1910. La Bible (French translation). Public domain. (SEG)

- LuTHER, Martin. Die Heilige Schrift (German translation). 1545. Public domain. (L45)

- Biblija. Russkij sinodal'nyj perevod (Russian translation). 1876. Public domain. Distribution: Rossijskoe Biblejskoe obščestvo. (RUS)

- Vulgata. (Latin translation), 4th-5th century (textual critical edition, 1969). Deutsche Bibelgesellschaft. (VUL)

\section{REFERENCES}

CERvONI, Jean, 1991: La preposition - Etude semantique et pragmatique. Duculot, Paris - Louvain - la Neuve, Belgique.

DANEš, František, 1999: Verba dicendi a výpovědní funkce. Jazyk a text I. Výybor z lingvistickeho díla Františka Daneše. Univerzita Karlova v Praze, Filozofická fakulta. Praha, 105-114.

DiRven, René (ed.), Verspoor, Marjolijn, (ed.) 200422: Cognitive Exploration of Language and Linguistics. J. Benjamins. Amsterdam, Philadelphia.

LANGACKER, Ronald W., 1991: Concept, Image, and Symbol. The Cognitive Basis of Grammar. Mouton de Gruyter. Berlin, New York.

RIzZI, Luigi, 19913: Il sintagma prepositionale. In: RENZI, Lorenzo (ed.), Grande grammatica italiana di consultatione. La frase. I sintagmi nominale e preposizionale. Vol. I. Il Mulino, Bologna.

SCHRÖDER, Jochen, 1986: Lexikon deutscher Präpositionen. VEB Verlag Enzyklopädie. Leipzig.

SICHERL, Eva, 2000: Sodobne jezikoslovne raziskave predložnih pomenov. Vestnik, Društvo za tuje jezike in književnosti Slovenije, 34/1-2, 413-424.

- - 2001: O predložni vezljivosti v angleščini in slovenščini. Vestnik, Društvo za tuje jezike in književnosti Slovenije, 35/1-2, 299-312.

ViDovič MuHA, Ada, 2000: Slovensko leksikalno pomenoslovje - Govorica slovarja. Filozofska fakulteta. Ljubljana.

WeINRICH, Harald, 1993: Textgrammatik der deutschen Sprache. Dudenverlag. Mannheim - Leipzig - Wien Zürich.

ŽELE, Andreja, 2001a: Vezljivost $v$ slovenskem jeziku (s poudarkom na glagolu). ZRC SAZU.

- - 2001b: Vezljivost kot pomensko- in strukturno skladenjski pojav. Slavistična revija 49/3, 137-161. 


\section{Povzetek \\ PREDLOŽNE ZVEZE OB GLAGOLIH GOVORJENJA IZ DALMATINOVEGA PREVODA BIBLIJE (1584) V RAZMERJU S TUJEJEZIČNIMI PREVODI}

$\mathrm{V}$ prispevku je $\mathrm{v}$ diahroni perspektivi od 16. stoletja do sodobnosti raziskana prevodna medjezikovna ujemalnost in različnost $\mathrm{v}$ rabi tistih časovno zaznamovanih slovenskih predložnih zvez, ki se pojavljajo v pomenski skupini glagolov govorjenja $\mathrm{v}$ prvih dveh starozaveznih in novozaveznih knjigah najstarejšega slovenskega prevoda Biblije iz l. 1584 in ki so jih v 19. stoletju zamenjali $\mathrm{v}$ sodobnem knjižnem jeziku uveljavljeni nepredložni ali drugi predložni vzorci. S primerjavo na podlagi internetne objave vzporedno izpisanih mest v šestih tujejezičnih prevodih (latinskem, nemškem, dveh angleških (iz 17. stoletja in sodobnem), francoskem in ruskem) je bilo ugotovljeno, v kolikšni meri se te predložne zveze prekrivajo s starejšimi ali sodobnimi slovenskimi knjižnimi skladenjskimi vzorci.

Iz medjezikovne primerjave svetopisemskih prevedkov pri izražanju udeleženskih vlog ob glagolih govorjenja glede rabe vezljivostno obveznih in prostih predložnih glagolskih zvez, ki v slovenskem jeziku ne izkazujejo kontinuitete, ampak so bile nadomeščene z brezpredložnim dopolnilom (tip govoriti, reči ipd. h komu, prositi od koga), blizupomenskim metaforično rabljenim predlogom (skozi po) ali navidezno pomensko različnim predložnim morfemom (od $-o$ ) lahko ugotovimo tujejezično prevodno navezavo oz. odvisnost, ki se večkrat omejuje le na nemški (ali širše germanski) slovnični jezikovni zgled kot posnemanje le-tega, ali pa lahko predvidevamo medsebojno jezikovno tipiko oz. skladnost na ravni predložnozvezne splošnosti rabe, ki izhaja verjetno iz globinske pomenske argumentacije, kot je razvidna npr. v tipu govoriti od koga/česa jezikovnorazvojna težnja po opuščanju pomensko neodločevalne predložne rabe pri glagolih usmerjenosti govorjenja na soudeleženca v govorni interakciji in tudi nekaterih drugih glagolskih pomenih (s sememom pridruženja, približevanja), ter težnja po pomenski razbremenjenosti oz. drugačni pomenski motivaciji nekaterih predlogov $(o d-o)$ v nekaterih jezikih (slovensko, angleško of - about) in s kontinuiteto v govorjeni jezikovni praksi. Pogostejša predložnosklonska glagolska raba v starejših obdobjih je bila kot druge skladenjske vzporednosti del zahodnoevropske civilizacijske in kulturne dediščine, za katero je bila značilna formalnojezikovna različnost in podobna pomenska motivacija. 